\title{
The Effect of Capital Adequacy, Asset Quality, and Liquidity on the Financial Performance of Shariah Rural Bank in East Java
}

\author{
Moch. Shultoni
}

\begin{abstract}
This study aims to analyze the effect of capital adequacy, quality of productive assets, and liquidity on financial performance. Financial performance is proxied by using Return On Assets (ROA). The population in this study is the Islamic Rural Bank (IRB) registered at Financial Services Authority. Sampling was conducted using purposive sampling method and total sample there are 100 samples. This research uses secondary time series data was published at official website www.ojk.go.id . The analytical method used is multiple linear regression by using SPSS 22 as tool to process the data and test the hypotheses. The result of this research indicate that capital adequacy has no significant effect on financial performance, while the quality of productive assets and liquidity has a significant effect on financial performance.
\end{abstract}

Keywords:- Financial Performance, Islamic Rural Bank, Multiple Linear Regression.

\section{INTRODUCTION}

The development of high globalization flows has influenced the development of the economy in Indonesia. In a country's economic sector, the role of banking is needed, namely that banking has an important role as a financial intermediary media in various sectors in a country. Every community activity in various countries including Indonesia, has used a variety of products produced by banks, both conventional and sharia, such as the use of demand deposits, deposits, credit systems, and various other banking products. In modern times, intervictim transactions can also be done in various places and at any time, the internet banking and sms banking features make it very easy for customers to carry out various transactions without having to go to a bank or automated teller machines (ATMs). Islamic law plays an important role in the financial sector in various countries, especially in Islamic countries, such as Indonesia. Bank activities that adhere to the principle of profit sharing or sharia are services offered by banks for people who want and need payments that are not based on the interest-interest system (usury). The rapid development of the number of Islamic banks in Indonesia is also supported by the number of Sharia Rural Banks (BPRS) developments which are increasing every year. Based on the results of the study, as of December 2011 the number of BPRS in East Java reached 30 banks and became the highest number in Java. In every city in East Java there is not only 1 bank, there are even 2 BRPS in 1 city. This shows that the development of
BPRS in East Java is very high. The purpose of establishing a Sharia Rural Bank is to improve the welfare of Islamic economics, especially the lower middle class.

The rapid development in the banking world, can affect the performance of a bank. High complexity can increase the risk faced by banks in Indonesia. Weakening of banking performance such as inadequate management structures, capital that cannot be used to cover the risks faced, and lending to groups can cause banking financial performance to decline. Declining banking financial performance can reduce the level of public confidence.Naser and Titik Aryati, (2000), said that there were several factors that caused the financial performance of a bank to decline. The banking liquidation that occurred on November 1, 1997 had an impact on the decline in the level of public trust in the government and banks in Indonesia, the decline in the rupiah exchange rate so that many banks were unable to cover their obligations, moral hazard, ie entrepreneurs did not report business results and profits that were honestly obtained, causing losses to Islamic Banks as capital owners, in this case entrepreneurs generally make two books, and what is reported to Islamic Banks is books that are not in accordance with the reality of the situation, as well as unfavorable corporate organizational structures that affect the level of effectiveness and efficiency in carrying out operational activities.

Factors affecting the financial performance of banks can be sourced from various indicators. The bank's financial statements are one of the main indicators that affect financial performance. By analyzing the bank's financial statements concerned can be obtained various financial and non-financial information. The information obtained can be used as a basis for making decisions and evaluating the financial performance of a bank.Various financing offered by Islamic Banks can affect the achievement of profitability in Islamic Banks. Profitability is as one of the references or bases in measuring and assessing the amount of profit in a company or bank in running its business efficiently (Harahap, 2008). The profit gained by the bank can be determined by how much financing is channeled. With the expectation that more and more financing is being distributed, the bank's profitability will also be reflected in increased profits. Where profits can be seen from the level of profitability of banks that can be measured by using financial ratio. One indicator of financial ratios used to measure bank profitability is Return on Assets (ROA), which is a ratio that shows the ability of all existing assets and which is used to generate profits. Based 
on ROA, it can be concluded how the health of banks and how optimistic the performance of a bank in managing assets can obtain high profits. The higher or greater ZROA of a bank, the greater the level of profits that banks achieve, and the better the bank's position in terms of the use of assets (Dendawijaya, 2005: 118).

In May 2017, the development of Islamic people's credit banks was said to be still vulnerable to bankruptcy. This can be reflected in the short-term financial performance indicators (liquidity) which are not immediately handled, resulting in various long-term financial difficulties (solvency) which will eventually lead to bankruptcy of a company. The phenomenon of bankruptcy in a banking system has been seen since the issuance of banking deregulation in 1983, where competition between banks, including state-owned, private, joint venture, and foreign banks, has increased. The positive performance shown by banks in East Java, namely BPRS is able to show its existence by gaining $8.26 \%$ (yoy) business volume growth, $11.05 \%$ DPK (yoy) and $21.97 \%$ Financing (yoy). The growth is considered higher and increased compared to the overall banking growth in East Java, which shows that the level of trust of the people of East Java in Islamic banking and especially BPRS has increased significantly. However, BPRS in East Java must make more efforts to increase the principle of prudence in channeling financing, given the risk of Islamic banking credit in East Java tends to increase significantly with the NPF ratio in May 2019 of $5.16 \%$. As part of the financial system in Indonesia, the Islamic banking industry especially the BPRS cannot be separated from the various challenges and problems that will be faced or faced today. The phenomenon of ups and downs in the development of Sharia Rural Banks occurred in several regions. Since 2015 until the end of April 2016, there have been 8 bprs that have been liquidated by OJK, of which two of them are Sharia Rural Credit Banks. In 2015 there were 3 Rural Bank and Sharia Rural Bank being liquidated, one of which was BPRS Hidayah Jakarta. Whereas in 2016, there were already 5 Rural Credit Banks and Islamic Rural Credit Banks that were liquidated by the OJK, one of which was the Al-Hidayah SRB located in Pasuruan, East Java. Research conducted by Widiya (2017) says that capital, asset quality, and liquidity do not have a significant effect on the performance of banking finance, while profitability has a negative effect on financial performance. Meanwhile, (2012) shows the results of research that capital adequacy has a negative effect and the quality of productive assets has a positive effect on financial performance.
Based on the explanation above, there have been several studies conducted to assess the financial performance of BPR Syariah by using the ratio of capital adequacy, quality of productive assets, and liquidity. And there are several phenomena that occur regarding the development of Sharia Rural Credit Banks, which have experienced growth or decline, resulting in several banks having to be revoked with the establishment of OJK permits. Some previous studies have produced inconsistent results. With the inconsistency of research results and the phenomena that are differences in the development of financial performance in accordance with financial data with existing theories, motivating researchers to conduct research regarding financial performance, especially in the Sharia Rural Credit Bank which is proxied by using the ratio of Return on Asset (ROA)

Based on the background description above, the problem problem in this research is whether capital adequacy has an effect on the financial performance of Islamic Sharia Rural Banks? Does the quality of productive assets (KAP) affect the financial performance of the Bank? Rural Credit? Sharia? Does liquidity affect the financial performance of Islamic Rural Credit Banks?

\section{METHOD}

This research uses quantitative research. This method provides a picture of the actual state of the object of research through data collection and analysis of data from the data that is processed and examined then will draw conclusions from the results. The approach used is a quantitative approach because the data needed is in the form of a company's financial statements. The population in this study were 28 BPRS registered at www.ojk.go.id, determining the sample with a purposive sampling method with the following criteria: (1) BPRS are banks registered at Bank Indonesia for the period 2014-2018 (2) BPRS has had a report financial succession began in the 2014-2018 period and was published on the official website of the Financial Services Authority (3) BPRS has complete data in accordance with the variables studied, namely capital adequacy, quality of productive assets, and liquidity. The type of data used in this study is quantitative data and time series data. Time series data is data that consists of several time intervals. The time series data from this study are in the form of the financial statements of the Islamic Sharia Bank Perkebunan from the period January 2014 to December 2018, which are published on the official website of the financial services authority (OJK). Regression analysis is the study of the dependence of the dependent variable with one or more dependent variables to predict the average value of the population or the average value of the dependent variable based on known values of independent variables. 


\section{RESEARCH RESULT}

\section{General Description}

The data used in this study is quantitative data in the form of a company's financial statements. This study took a sample at the Sharia Rural Bank registered with the Financial Services Authority during 2014-2018, amounting to 28 BPRS with a total sample of 100 samples (20 BPRS in 2014-2018). The list of companies used in this study is presented in the following table:

\begin{tabular}{|c|c|c|}
\hline No & Criteria & Total \\
\hline 1 & BPRS in East Java in 2014-2018 & 28 \\
\hline 2 & BPRS that do not routinely make financial reports in 2014-2018 & 2 \\
\hline 3 & BPRS which do not have complete data based on the variables & 20 \\
\hline & The company who presented & 100 \\
\hline
\end{tabular}

Table 1

Source: www.ojk.go.id 2019.

Data Analysys

The results of the secondary data regression analysis can be seen in Table 1 as follows:

\begin{tabular}{|c|c|c|c|}
\hline Variable & Coefficient Regression & Sig. & Info \\
\hline Constanta & 0,04 & - & - \\
\hline KM & 0,044 & 0,610 & unsignificant \\
\hline KAP & 0,297 & 0,015 & significant \\
\hline LK & 0,541 & 0,001 & significant \\
\hline
\end{tabular}

Table 2

Source: processed

T Test

$\mathrm{T}$ test in multiple linear regression analysis has the intention to find out whether the independent variable $(\mathrm{X})$ partially has a significant effect on the variable $(\mathrm{Y})$. $\mathrm{T}$ test results are as follows:

\begin{tabular}{|c|c|}
\hline Variable & Sig. \\
\hline KM & 0,610 \\
\hline KAP & 0,015 \\
\hline LK & 0,001 \\
\hline
\end{tabular}

Table 3

Source: processed

\section{DISCUSSION}

\section{Effect of Capital Adequacy on Financial Performance}

The results of multiple linear regression analysis on the $t$ test of the first hypothesis (H1) can be seen in Table 1 that Capital Adequacy does not affect Financial Performance by looking at the significance level of 0.610 , meaning that the higher the Capital Adequacy the Financial Performance will not change (H1 rejected ). Capital conditions in the 5 year study period (2014-2018) were considered to be very good. Where the average CAR is $40.6 \%$, which means it is far above the minimum CAR standard set by the government of $8 \%$. This condition explains that banks do not rely on all their potential capital to improve financial performance, banks rely more on loans as a source of income. This causes CAR not to be a factor that has a significant effect on financial performance of banks.

\section{Effect of Assets Quality on Financial Performance}

The results of multiple linear regression analysis on the $t$ test of the second hypothesis (H2) can be seen in Table 1 that Earning Asset Quality has a positive effect on Financial Performance by looking at the significance level of 0.015, meaning that the higher the Earning Assets Quality will increase the Financial Performance (H2 received ). Poor quality of productive assets will cause banks to suffer losses because they do not get profits. The quality of improved financial performance must be maintained even if possible. However, if financial 
performance continues to decline, there must be direction and evaluation.

\section{Effect of Liquidity on Financial Performance}

The results of multiple linear regression analysis on the $t$ test of the third hypothesis $(\mathrm{H} 3)$ can be seen in Table 1 that Liquidity has no effect on Financial Performance by looking at the significance level of 0.134 , meaning that the higher the Liquidity means that the higher the Quality of Earning Assets will increase Financial Performance (H3 received). A bank is considered liquid if it has the same amount of liquidity as the amount of liquidity needed, has less liquidity than needs but the bank has securities that can be immediately converted into cash, and has the ability to obtain liquidity by creating debt.

\section{CONCLUSION}

This study aims to examine the effect of capital adequacy, the quality of productive assets, and liquidity on the financial performance of the Sharia Rural Bank of East Java Province in the 2014-2018 period. Based on the sample used in this study, as many as 20 BPRS were registered at the Financial Services Authority in 2014-2018 and determined by purposive sampling method.Capital Adequacy does not affect the financial performance of Islamic Rural Banks in 2014-2018, because the probability level $(\alpha)$ is 0.610 with a significant value of capital adequacy variable $>0.05$ then $\mathrm{H} 1$ is rejected in other words that Capital Adequacy does not affect the Financial Performance of Credit Banks Sharia People.Earning Assets Quality on the financial performance of Sharia Rural Banks in 2014-2018, because the probability level $(\alpha)$ is 0.015 with a significant value of Earning Assets Quality 0.05, then $\mathrm{H} 2$ is accepted in other words Earning Assets Quality affects the Financial Performance of Credit Banks Sharia People.Liquidity does not affect the financial performance of Islamic People's Credit Banks in 2014-2018, because the probability level $(\alpha)$ is 0.134 with a significant value of liquidity variable $<0.05$, then $\mathrm{H} 3$ is accepted in other words Liquidity affects the Financial Performance of Islamic People's Credit Banks.

\section{REFERENCES}

[1]. Agustiningrum, Riski. 2013. Analysis of the Effect of CAR, NPL, and LDR on Profitability in Banking Companies. E-Jurnal Manajemen. Universitas Udayana.

[2]. Aini, N. 2013. Effect of CAR, NIM, LDR, NPL, BOPO and Earning Assets Quality on Profit. Dinamika Akuntansi, Keuangan dan Perbankan, 2 (1), $14-25$.

[3]. Almilia \& Herdiningtyas, W. 2005. Analysis of CAMEL Ratio to Prediction of Problematic Conditions in Banking Institutions for the Period 2000-2002. Accounting and Financial Journal, Vol, 7, No, 2, November.

[4]. Bachri, S., Suhadak. \& Saifi, M .2013. Effect of Financial Ratios on Financial Performance of Islamic Banks. Jurnal Administrasi Bisnis, Vol.1, No. 2.
[5]. Dendawijaya, L. 2009. Manajemen Perbankan. Bogor: Ghalia Indonesia.

[6]. Fahmi, M.S. 2013. The Effect of CAR, NPF, BOPO and FDR on the Profitability of Islamic Commercial Banks. Jurnal Ekonomi dan Disertasi, 7(2), Maret 2013.

[7]. Fitriyana, A. \& Mawardi, W. 2011. Analysis of the Influence of Capital Adequacy Ratio, Liquidity, Non Performing Loans, Equity To Asset Ratio and Time Deposit Ratio Against Bank Return On Assets (Empirical Study on Conventional Commercial Banks in Indonesia 2006-2010 Period). dissertation, Universitas Diponegoro.

[8]. Ghozali, Imam. 2011. Aplikasi Analisis Multivariate Dengan Program SPSS. Semarang : BP Universitas Diponegoro.

[9]. Harianto, Syawal. 2017. Financial Ratios and Their Effects on Profitability at Islamic People's Financing Banks in Indonesia. Jurnal Bisnis dan Manajemen Politeknik Negeri Lhokseumawe. Vol. 7, No.1, April.

[10]. Iswandari, Mona dan Edy Anan. 2015. The Financial Performance of People's Financing Banks and Islamic People's Financing: Case Studies in Special Region of Yogyakarta. Jurnal Akuntansi STIEBBANK Yogyakarta. Vol. 11, No. 1, Februari.

[11]. Kasmir. 2011. Analisis Laporan Keuangan. Jakarta: PT. Raja Grafindo Persada.

[12]. Kurniasari, C. \& I. Ghozali. (2013). Analisis Pengaruh Rasio Camel Dalam Memprediksi Financial Distress Perbankan Indonesia Periode 2009-2012. Diponegoro Journal Of Accounting. Vol. 2. No 3: 1-10.

[13]. Listyorini. 2012. “Analisis Pengaruh Camel terhadap Kinerja Perusahaan Perbankan yang Go Publik."Jurnal Akuntansi, Keuangan dan Perbankan, Vol.1, No.2, November hal 105- 119.

[14]. Luh, Nyoman Trisna dan Luh Gede. 2015. “Analisis Pengaruh NIM, BOPO, LDR dan NPL terhadap Profitabilitas."Jurnal Akuntansi, Vol. 3, No. 1.

[15]. Lyla Rahma A. Dan Djoko Sampurno.2011. Analisis faktor-faktor yang mempengaruhi Profitabilitas (ROA). Jurnal Dinamika Ekonomi dan Bisnis, 8 (1).

[16]. Margaretha, Farah dan Letty. (2017). Faktor-Faktor Yang Memengaruhi Kinerja Keuangan Perbankan Indonesia. Jurnal Manajemen Keuangan Vol. 6 No. 2. Mei.

[17]. Mawaddah, N. (2015). Faktor-faktor yang Mempengaruhi Profitabilitas Bank Syariah. Etikonomi. Vol. 14 (2): 241-256.

[18]. Mismiwati. 2016. "Pengaruh CAR, NIM, BOPO, LDR dan NPL terhadap ROA."Jurnal Keuangan, Vol. 2, No. 1, Juli hal 55-74.

[19]. Muhamad. 2014. Manajemen Dana Bank Syariah. Jakarta:Rajawali Pers.

[20]. Ningsih, Widya. 2017. Pengaruh Permodalan, Kualitas Aktiva Produktif, Rentabilitas, dan Likuiditas Terhadap Profitabilitas Bank Pembiayaan Rakyat Syariah di Indonesia. Jurnal Akuntansi Universitas Sultan Agung Tirtayasa, Banten. Vol. 10, No. 1, April. 
[21]. Peraturan Otoritas Jasa Keuangan No. 20/POJK.03/2014 tentang Bank Perkreditan Rakyat.

[22]. Pribadi, I. S. 2013. Analisis Perbandingan Rasio Keuangan Bank Perkreditan Rakyat Konvensional dan Bank Perkreditan Rakyat Syariah di Jawa Timur Thesis. Universitas Jember.

[23]. Putu, Fridayana dan I Wayan. 2014. Pengaruh Non Perfoming Loan (NPL), Loan to Deposit Ratio (LDR) dan Net Interest Margin (NIM) terhadap Return On Asset (ROA) pada Bank Umum yang Terdaftar di Bursa Efek Indonesia Tahun 2014. e-Journal Bisma Unisversitas Pendidikan Ganesha, Vol. 4 Tahun 2016.

[24]. Sidik, P.P. 2013. Analisis Pengelolaan Liquidity Risk, Credit Risk Ratio, Deposit Risk Ratio, Capital Ratio, Risk Asset Ratio Terhadap Return On Asset (ROA). Jurnal Keuangan \& Manajemen, Vol 5, No. 3.

[25]. Yunita, R. (2014). Faktor-faktor yang Mempengaruhi Tingkat Profitabilitas Perbankan Syariah di Indonesia (Studi Kasus Pada Bank Umum Syariah di Indonesia Tahun 2009-2012). Jurnal Akuntansi Indonesia. Vol. 3. 